\title{
Managing Research and Development for Core Competence Building in an Organization
}

\begin{abstract}
The uncertainties due to globalization of Indian market after economic reforms have led to drastic changes in the approach of manufacturing organizations for developing various competencies to get competitive advantage. These formidable changes have left the organizations with no choice but to upgrade the existing systems, products and technologies for their survival. The external acquisition of technology in the initial stages may be desirable or even necessary in the high technology areas, but no industry can prosper in the long run unless it builds up a self reliant base for carrying out indigenization of process and product technologies. Technology upgradation has become mandatory for economic development, industrial growth, enhanced corporate image, more flexible responses, strategic self-reliance and sustained competitiveness of an enterprise. The present study is aimed at highlighting the need of R\&D initiatives in Indian enterprises for harnessing competencies through indigenized R\&D.
\end{abstract}

Keywords: India; globalization; technology upgradation; R\&D; innovation; competitiveness.

'Department of Mechanical Engineering, University College of Engineering, Punjabi University, Patiala - I47002, Punjab, INDIA. Tel. +91-9501533/13 - E. mail: ahujaips@yahoo.co.in 


\section{Introduction}

In the modern dynamic world, the society is steadily shifting to a fast track of economic and industrial development. The world of technology is in the state of rapid change and changes in the economic and industrial scenario are taking place at a rapid pace. The nations are now on the verge of immense technological change and knowledge revolution. In the modern age, technology is perhaps the most important resource to any nation. Technology and its management are today matters of global primacy. Technological developments, in the areas of both product and process technologies are taking place at a very fast pace (Rathore, 200I). Shortening of product life cycles, rapid innovation, inventions and product developments are indicators to the fast changing manufacturing scenario. The economic activities are moving in the direction of globalization. It is creating new structures and new relationships, with the result that business decisions and actions in one part of the world are having significant consequences in other places. Underlying and reinforcing these globalization trends is the rapidly changing technological environment (Muhammad et al., 2010). Increasing global competition coupled with rapidly changing technology, and shortening of product life cycles, have made corporations vulnerable to failure more than any time in the past (Jalan and Kleiner, 1995).

Today the industries worldwide are faced with new era of global competition and manufactures are forced to achieve world-class status to compete effectively in the global market. Organizations, which are able to continually build new strategic assets faster and cheaper than those of their competitors, will create long-term competitive advantages (Ajitabh and Momaya, 2004). Further the recent advancements and rapid growth in the field of information technology has opened up the floodgates and led to globalization of economies and has resulted in the global competition between the organizations (Vanden Kroonenberg, 1989; Leonard-Barton, 1991). As the organizations around the world are faced with dynamic environments, the technology up-gradation has become key factor for the organization's survival and prosperity on the long-term basis. The need of the hour is to achieve more product variety, shorten the delivery times and achieving greater flexibility of manufacturing functions.

The advent of liberalization, Privatization and Globalization has brought forth profound economic, social, environmental and technological pressures. Today the world is moving from an era of separate national economies to the networked global economy. Markets have become more open, competitive and the customers are more demanding. Competition is fierce in all aspects of the business such as technology, cost, product quality and service quality and the product quality has become strategic variable for effectively competing in the global market (VandeVen, 1986). The organizations worldwide are faced with stiff, cutthroat competition that is marked by rapid technological developments and unprecedented obsolescence rates. These formidable changes have forced the organizations around the world to adopt innovative and state of the art strategies to suitably address the all-important issue of organization survival, growth and excellence. Thus the organizations are left with no choice but to upgrade the existing systems, products and technologies for their survival (Martins and Terblanche, 2003; Yang, 2007). The top competitive issues facing industry today include the following:

a. Deliver high quality products through continuous improvements in product features, reliability and service.

b. Bring new products to market faster.

c. Make product design changes faster and more manageable.

d. Improve forecasting accuracy of product demands.

e. Reduce costs.

f. Improve employee training, skills, and education levels.

g. Improve Information Systems and Networks

In order to address the top competitive issues facing the industry and meet the demands of today's complex manufacturing system, successful firms across the world are continuously making efforts in meeting pace with new technologies. Thus, continuous up-gradation of technology has become essential for survival of any manufacturing unit. Without continuous technology up-gradation, no enterprise can ever remain competitive.

In this highly competitive global scenario, technology upgradation has become mandatory for economic development, industrial growth, improved organization, enhanced corporate image, more flexible responses, strategic selfreliance and sustained competitiveness of an enterprise (Giorgio, 2000). Thus technology up-gradation efforts must be placed within the context of market opportunity, customer needs and strategic direction, thereby leading to improving the product and technology portfolio. 
J. Technol. Manag Innov. 20II,Volume 6, Issue I

\section{Need for Research \& Development in the Organizations}

In the modern dynamic world, competition is the driving force behind technological and institutional change. The world is fast turning into a global village that provides unlimited access to the technologies and products of the entire world to everybody. Today, technology is the main driver of economic development of any nation. Thus, organizations across the globe are faced with the task of developing indigenous technologies and products to enhance their competitive edge thereby contributing to evolution of national wealth in all segments of economy (Cagliano, 2000). Thus, in this rapid paced environment, the organizations are faced with challenge of bringing forth a steady stream of new products and technologies. Thus the organizations have to learn to stretch themselves in order to create new products and technologies and identify new market places and challenge before the organizations is how can they create their own successful future.

To achieve the developmental goals of an enterprise for technology up-gradation, there are two options: first, the technology can be developed indigenously through inhouse R\&D; secondly, it can be acquired from an external source within the country or abroad (Ettlie, 1998). The first option of indigenous development of technology is quite expansive, both in terms of time and money, as it requires extensive technical / scientific manpower and R\&D infrastructure. In addition to this, the shortening technological life cycles also make it extremely difficult for the organizations to make investments in R\&D activities.

As the organizations are faced with dynamic environment and the product and technology life cycles are also getting shortened, the technologists are left with very short reaction time for harnessing the heavy investments required for indiginizing the R\&D activities within the organization (Pegels and Thirumurthy, 1996). Thus the organizations in the past have reacted to this situation by putting onus on shortening the learning time and reacting faster to rapidly changing technological environment through the strategic networking for obtaining new technologies for providing technological solutions to a large number of organizational problems and bottlenecks. The enterprises in most of the developing countries have often depended on other advanced countries for acquisition of technology, taking into account their market needs and resources. Thus, many enterprises in the developing countries have considered the external technology acquisition for mitigation of existing and perspective technological problems.

Here it must be well understood that, while the external acquisition of technology in the initial stages may be desirable or even necessary in the high technology areas, but no industry can prosper in the long run unless it builds up a self reliant base for carrying out indiginization of process and product technologies. It is the right time that the organizations learn to embrace change, as development of advanced technologies help in improving the competitive position of the organization and the full advantage of such technologies cannot simply be purchased off- the-shelf; these can be obtained by carefully tailoring the technology to fit into the organization's strategic goals and objectives (Marco, 1993).

Moreover it is also not possible for the organizations to acquire state-of-art technologies from the external sources due to the basic reason that no entrepreneur ever offers state-of-art technology at terms that are suited to encourage the growth and development of the organization and that might lead to the capability building of the organization. This leads to the situation wherein organizations are forced to follow the state-ofart technology based on the black-box approach and in no way empowers the organizations to adapt the technology towards building up of technological know-how for developing core competencies within the organization to suit its strategic and business requirements (Liyanage, 1999). Moreover in many situations, even if state-of-art technology is made available to the organizations, it is usually not affordable by the organization to effectively and economically adopt / absorb the technology into its operations. Thus, in order to achieve sustained competitive edge over the competitors in the global market, the organizations are faced with the challenge of indiginization of the product and process technologies through research and development and incremental process innovations as process innovations lead to the development of core competencies within the organizations. 
Global competition, technological change, and demanding customers are creating a more knowledge intensive, turbulent, complex and uncertain environment. Creating new forms of competitive advantage has become major area of concern for management in such an uncertain and competitive environment (Singh, Garg, Deshmukh, 2008). The fierce competitive situation arising out global competition is forcing the organizations across the globe to realize that the mere survival act is also not feasible in the absence of research and development and innovation practices in the contemporary global scenario (Takahashi, 1997). For the industry to stay 'alive' and remain competitive, it must innovate. Innovation is therefore portrayed as the backbone of any industry (Pichard et al., 2008). It is therefore the right time for the industries to wake up and gear up for research and development initiatives to develop cutting edge technologies for sustained competitive advantage in the global market place. In today's business world successful product or process innovation provides companies with major opportunities and advantages. Successful innovation is increasingly important in the globally competitive economy (Regan, Ghobadian, Gallear, 2006).

The global competitive scenario requires constant review of the existing product and process technologies; strengthening of the prevailing knowledge base to develop cutting edge technologies and products to satisfy the customer's requirements in performance, state-of-art quality, reliability at an affordable price (Perez, 1998). As the organizations across the world find it extremely difficult to compete in the global market through the strategies like external technology acquisition without familiarization to the technologies, they are forced to adopt the strategy of transforming the organization into a learning organization, thereby assimilating and integrating the knowledge towards development of new and improved innovative product and process technologies (Palhan, 1991).

\section{Objetives of Technological Developments Through R\&D}

The main objectives of an enterprise going for technology up-gradation / technological developments through Research and Developmental activities include the following:
a. Enhanced infra-structural facilities
b. Enhanced corporate image
c. Increasing manufacturing agility
d. Early development of in-house expertise
e. Diversifying into new product markets
f. Extended proprietary positions and rapid ramp up
g. Improving product mix
h. Restructuring mature / declining product lines
i. Reducing technological gap behind competitors
j. Improved responsiveness to changing market demands
k. Achieving consistency in quality
I. Greater reliability of products
m. Improved resource utilization
n. Fostering good vendor relationships
o. Accelerated time to market
p. Better process control
q. Low cost of meeting demand
r. Improving the skill base
s. Broadening of product lines

\section{Indian Technology and R\&D Scenario}

Globalization and liberalization of economy have tremendously changed the industrial scenario in our country. The industrial scenario has undergone a sea-change consequent to the liberalization and globalization that began in early nineties. India was in a protected environment till 1990. India had the license regime; entry into businesses was very much restricted with certain sectors like telecommunication, airways under monopolistic situation. Whatever goods produced had to be accepted, as there was no alternative available. Prior to liberalization, privatization and globalization, cost was not a major factor for the Indian domestic entrepreneurs and whatever price was fixed by the supplier, had to be paid by the customer while there was little or rather no focus on providing service to the customers. It sued to be the seller's market wherein very little emphasis was given to continuously improving the product quality and providing state-of-art products regularly into the market. But after opening up of the economy, competition came in - both from local and from abroad. All of a sudden the customer has recei- 
ved all the importance. The secret for this sudden change is the onslaught of competition. Now it is the question of survival of the fittest. The uncertainties due to globalization of the Indian market after economic reforms have led to drastic changes in the approach of manufacturing organizations for developing various competencies to get competitive advantage. The new competition is in terms of reduced cost, improved quality, products with higher performance, a wider range of products with better service, and all delivered simultaneously (Nanda and Singh, 2008).

According to the Global Competitiveness Report, 20092010, published by Harvard Institute, India ranks fourth in the world on the factor of availability of scientists and engineers, yet it ranks at 43 out of 133 nations on overall technological sophistication. The paradox is very stark. On one hand India has developed, nuclear capabilities and has shown lot of strength in the areas of satellite communication, missile technology but on the other performs badly in the export of capital equipment. The pattern of technology funding by Indian government, does not reflect priorities inferred from economic development and growth objectives. An analysis of R\&D expenditure in India shows that funding for technology in specific sectors is not in consonance with the size of domestic or global markets. In India, too much of research and development effort is expended in the public sector. Over $80 \%$ of the funding for R\&D comes from the government and almost all of this is spent in government run organizations. India stands at number 36 on private sector spending on R\&D among 133 developed and emerging economies. The country ranks 46 on research collaborations between the universities and industry. All high technology businesses across the globe have academic ties wherever they are located. This type of industry - institute interaction lacks in India with a ranking of 46 out of 133 countries (Global Competitiveness Report, 2009-2010).

Today the biggest challenge before the Indian industry is to generate the knowledge base for producing technologies and core competencies to remain competitive globaIly. Unfortunately, the research and development scenario in the country is not very encouraging at the present moment. The Global Competitive Report, 1988 published by Harvard Institute puts India in 53rd position out of 53 developed and emerging technologies. This ranking does not do justice to the inherent potential of Indian companies to achieve international levels of competitiveness. Moreover the research and development investments in India are very low, ranging between $0.2 \%-0.5 \%$ of the total turnover compared to $2.5-18 \%$ in the case of organizations across the globe. In addition to this, the Indian industry in the past has often been often motivated and guided by the technology inputs from the foreign collaborators. Thus the industry has neglected to foster the healthy relationship between the industry and research and development establishments. A near total disconnect between the industry and research and development establishments in the country has been hampering the country's efforts towards achieving technological excellence and self reliance in this highly competitive environment.

In the pre-liberalized Indian economy, not many organizations had bothered to invest in research and development. Now, ever since the opening up of the Indian economy, the Indian entrepreneurs are constantly feeling the heat of fierce and cutthroat unlimited competition. With the Multinational Corporations entering into the Indian marketplace with better core capabilities and much superior research and development infrastructure facilities, the Indian entrepreneurs are finding it extremely difficult to compete with their global counterparts as their age old practices of over dependence on external technology acquisitions to compete effectively in the marketplace have rendered their available technologies and skills obsolete, inefficient and outdated.

The industrial scenario in India has undergone a sea-change consequent to the globalization and liberalization of economy. This competition is marked by rapid technological developments and unprecedented obsolescence rates. Today, the biggest challenge before the Indian industry is to generate the knowledge base for producing technologies and core competencies to remain competitive globally. This requires extensive research and development efforts for indigenous technology development. The over dependence of the Indian firms on external technology acquisition have rendered their available technologies and skills obsolete, inefficient and outdated. They should move away from their complacent technology development and innovation initiatives and start managing innovation in research and development activities to develop cutting edge technologies and products.

With the state-of-art technology not available easily offthe-shelf, the Indian entrepreneurs are left with no option but to wake up and harness their resources, in particular their much-neglected human resources for effectively 
J. Technol. Manag Innov. 20II,Volume 6, Issue I

and efficiently competing with their global counterparts. Organizational structure should be such that there are adequate funds, materials, production facilities and information support system to sustain innovation (Amabile et al., 1996; Ghorbani and Bagheri, 2008). Government should concentrate on quality strategy development, goal stretching, continuous improvement and concurrent engineering programmes contributing to the creation of innovation context (Bossink, 2002; Avnimelech and Teubal, 2008). Governments should develop policies for technological innovations, both on a global and local scale, using especially tools geared towards improving the links between firms and research. These tools involve creation of infrastructures for assistance and technological transferal. Among these tools, a key role is played by an effective network of service centers, development agencies and technological parks, suitably linked to local public or private bodies, providing a real support to the innovation needs of firms (Cariola, 2009; Henrik et al., 2009). Increase in technological innovation demands that government should enhance the extent of investment on R\&D and training of employees through targeted expenditure and collaborative research programs (Liyanage, 2003; Regan, Ghobadian, Gallear, 2006; Fajnzylber, Maloney, Montes-Rojas, 2009). The Government should support programs to build infrastructure as well as incentives (such as tax incentives) and special start-up programs to develop private sector. Factors under infrastructure facilities are related to transport, market information, credit, power, water, telecom, technology upgradation and quality certification; noninfrastructure category includes interaction with government, taxation, and manpower availability (Thomas, 1993; Sheel, 2002; Hyland, 2004). Facilitating access to credit and business development services and promoting formalization, will lead to increase in increase firm's growth (Shi et al., 2008; Fajnzylber, Maloney, Montes-Rojas, 2009).

The Indian entrepreneurs have understood that competitiveness can only be achieved through undisputed customer orientation through timely and flexible responses to the market-place requirements. Therefore economic liberalization and consequent global competition have forced the Indian industries to move away from their traditional complacent technology development and creation initiatives and adopt the strategy of continuous improvement, innovation and research for keeping pace with rapidly changing global scenario. Thus, it is the right time that Indian industries gear up research and development activities to develop cutting edge technologies and products.

\section{Conclusions}

The business environments are witnessing a rapid change in today's highly competitive and fast growing marketplace. The requirements of the present customers and potential customers are undergoing drastic changes due to wider exposure, customer education that is driven by hardcore competition. To stay close to the customers is essential for sustained growth and continuity of business. This places all organizations to continue to evaluate customer's needs and problems and take a best possible course of action to satisfy them, as customer's satisfaction is the measure of success of an organization. Thus, continuous supply and development of excellent quality products, services at competitive prices, timely delivery and after sales service are being viewed as key strategies for sustained growth and development of an organization.

India is a fast growing economy and has been making impressive economic progress in the last few years despite many daunting challenges on the socio-political fronts. With arguably a very high level of availability of technical and scientific manpower in the country, the government should tap this vast potential of human resource in order to gain an upper hand in research and development. This is possible only when we are able to prioritize our research and development activities and right policies are not only framed but also effectively and religiously implemented to encourage the human resources to take up the research and development activities.

\section{References}

AJITABH, A., Momaya, K. (2004). Competitiveness of firms: review of theory, frameworks and models. Singapore Management Review, 26(I), 45-6I.

AMABILE, T.M., Conti, R., Coon, H., Lazenby, J., Herron, M. (1996). Assessing the work environment for creativity. Academy of Management Journal, 39(5), II54-II84.

AVNIMELECH, G., Teubal, M. (2004). Strength of market forces and the successful emergence of Israel's venture capital industry: Insights from a policy-led case of structural change. Revue économique, Presses de Sciences-Po, 55(6), 1265-1300.

BOSSINK, B.A.G. (1999). The strategic function of quality in the management of innovation. Journal of Total Quality Management, 13(2), I-23. 
CAGLIANO, R., Chiesa, V., Manzini, R. (2000). Differences and similarities in managing technological collaborations in research, development and manufacturing: A case study. Journal of Engineering and Technology Management, 17(2), 193-224.

CARIOLA, C. (2009). Education, research and innovation policy: A new direction for Iceland. Report prepared on behalf of the Icelandic Government, the Ministry of Education, Science and Culture, May 2009, I-24.

ETTLIE, J.E. (1998). R\&D and global manufacturing performance. Management Science, 44(I), I-II.

FAJNZYLBER, P., Maloney, W.F., Montes-Rojas, G.V. (2009). Releasing constraints to growth or pushing on a string? Policies and performance of Mexican micro firms. Journal of Development Studies, 45(7), 1027-1047.

GHORBANI, A.A., Bagheri, E. (2008). The state of the art in critical infrastructure protection: a framework for convergence. International Journal of Critical Infrastructures, 4(3), 215-244.

GIORGIO, G. (2000). How Technology should be managed in the post - Fordist era. International Journal of Technology Management, 3(I/2), I-9.

HENRIK, H., John Rand, J., Finn T. (2009). Enterprise growth and survival in Vietnam: Does government support matter?, Journal of Development Studies, 45(7), 1048-1069.

HYLAND, P.W. (2004). Innovation and enhancement of enterprise capabilities. International Journal of Technology Management, 3(I), 35-46.

JALAN, A., Kleiner, B.H. (1995). New developments in developing creativity. Journal of Managerial Psychology, 10(8), 20-23.

LEONARD-BARTON, D. (1991). The role of process innovation and adaptation in attaining, strategic technology capability. International Journal of Technology Management, 6(3/4), 303-320.

LIYANAGE, S. (1999). Towards a fourth generation R\&D management model research networks in knowledge management. International Journal of Technology Management, 18(3/4), 372-393.
LIYANAGE, S. (2003). Technology and innovation management learning in the knowledge economy. Journal of Management Development, 22(7), 579-602.

MARCO, I. (1993). Real-world R\&D: Jumping the product generation gap. Harvard Business Review, 36(4), I38-146.

MARTINS, E.C., Terblanche, F. (2003). Building organizational culture that stimulates creativity. European Journal of Innovation Management, 6(I), 64-74.

MUHAMMAD, M.Z., Char, A.K., Yasoa, M.R., Hassan, Z. (2010). Small and medium enterprises (SMEs) competing in the global business environment: $A$ case of Malaysia. International Business Research, 3(I), 66-75.

NANDA, T., Singh, T.P. (2008). A Comprehensive strategy for technology generation through effective industryinstitute bonding. The Indian Journal of Technical Education, $3 \mathrm{I}(2), \mathrm{I}-6$.

PALHAN, S.K. (1991). How to Negotiate foreign collaborations/ technology transfer. Maintenance, April-June, 12-22.

PEGELS, C., Thirumurthy, M.V. (1996). The impact of technology strategy on firm performance. IEEE Transactions of Engineering Management, 43(3), 246-249.

PEREZ, P.D. (1998). What hurts, What helps, What is needed. Managerial cognitions about technology and innovation in emerging economies. IEEE International Engineering and Technology Management Conference, October II-I3, San Juan, PR, USA, 546-55I.

PRICHARD, C., Hulle, R., Churner, M. and Willmott, H. (2008). Nine drivers of knowledge transfer between universities and industry R\&D partners in South Africa. South African Journal of Information Management, 9(I), 35-62.

RATHORE, B.S. (200I). Quality technical education: Challenges and strategic issues. Proceedings of Ist R\&D Symposium on The R\&D Challenge before the Indian Industry: Time to have a look at ourselves, May 19-20, T.I.E.T., Patiala, Punjab, India, I46-I53.

REGAN, O.N, Ghobadian, A, Gallear D. (2006). In search of the drivers of high growth in manufacturing SMEs. Technovation, 26(I), 30-4I. 
SHEEL, C. (2002). Knowledge clusters of technological innovation. Journal of Knowledge Management, 6(4), 356-367.

SHI, H., Peng, S.J., Liu, Y., Zhong, P. (2008). Barriers to the implementation of cleaner production in Chinese SMEs: government, industry and expert stakeholders perspectives. Journal of Cleaner Production, I6(7), 842-852.

SINGH, R.K., Garg, S.K., Deshmukh, S.G. (2008). Competency and performance analysis of Indian SMEs and large organizations: An exploratory study. International Business Journal, 18(4), 308-321.

TAKAHASHI, T. (1997). Management for enhanced R\&D productivity. International Journal of Technology Management, 14(6/7/8), 789-805.

THOMAS, L.G. (1993). Implicit industrial policy: The triumph of britain failure of finance in global pharmaceuticals. Competitiveness Reviews, 29(3), 9-18.

VANDEN-KROONENBERG, H.H. (1989). Getting a quicker pay-off from R\&D. Long Range Planning, 22(5), 5I-58. VANDEVEN, A.H. (1986). Central problems in the management of Innovation. Management Science, 32(5), 590-607.

YANG, J. (2007). The contingency value of knowledge in new product creativity. International Journal of Technology Management, 40(I/2/3), I0I-II3. 